\title{
THE INVENTORY OF THE ORNITOFAUNA OF SARATA NOUA LAKE, LEOVA COUNTY, REPUBLIC OF MOLDOVA FROM 2016 - 2021
}

\author{
Vitalie Ajder ${ }^{1,2,3}$, Silvia Ursul ${ }^{1,2}$ \\ ${ }^{1}$ Society for Birds and Nature Protection, Chișinău, Republic of Moldova \\ ${ }^{2}$ Institute of Zoology, Chișinău, Republic of Moldova \\ ${ }^{3}$ Institute of Ecology and Geography, Chișinău, Republic of Moldova \\ ajder.vitalie@gmail.com, lavricsilvia@gmail.com.
}

\begin{abstract}
The Republic of Moldova is a small European country where long-term studies have been more of an exception than a rule. Being an agrarian country, the mosaic of natural and artificial habitats is found on a smaller scale, namely in the Sărata river meadow, and in Sărata Nouă lake and surrounding. The Sărata River is a right tributary of the Prut River in the Republic of Moldova, having a quiet plain character, with a mosaic of natural and artificial habitats which are traditionally managed. The area overlaps with the East-Elbic migration route, the short distance to the Prut River and being located in the northern part of the Bugeac steppe, ensures a great diversity both in winter and nesting, and especially in the migration period. During 2016-2021, we registered the presence of 126 bird species, which represent $46 \%$ of the total species encountered in the Republic of Moldova.
\end{abstract}

\section{Introduction}

The Sărata Nouă Lake is an average-sized lake located in the middle course of the river Sărata, which is a tributary of the Prut river in the Republic of Moldova. The Sărata river has a total length of $59 \mathrm{~km}$ [2], while the Sărata Nouă lake has a water surface of 139.50 hectares, according to „Apele Moldovei” Agency [9].

The Sărata Nouă lake is located near the village of the same name, situated in the Leova country. In the Sărata river meadow and on the related slopes there are 14 villages with a total population of over 16 thousand people [8]. The river basin is located in the northern part of the Bugeac steppe, having its springs from the village Sarata-Mereșeni (Hîncești county). The upper course of the river has a southern direction, while the middle is oriented southeast. Near the place where it flows into the Prut river (Nicolaevca village, Leova county) it turns sharply to the west [3]. The lake is located on the middle course of the river Sărata.

In the Sărata river basin there are over 60 artificial ponds, which are used mainly for irrigation and fish farming. The largest artificial lakes are Sărata Nouă, Cneazevca, Caracui and Sărata Galbenă. The fact that the area overlaps with the East-Elbic migration route [4], the short distance to the Prut River and being located in the northern part of the Bugeac steppe [5], ensures a great diversity both in winter and nesting, and especially in the migration period.

There are no exhaustive studies describing the location and geographical features of the Sărata Nouă lake, and also there is no study regarding the ornitofauna of the Sărata river basin or particularly on Sărata Nouă Lake.

\section{Materials and methods}

Because wetlands are among the most threatened ecosystems [7] it is very important to have permanent monitoring of biodiversity in general and of waterbirds in particular, due to 
their capacity to indicate the changes in wetlands. This is why we selected as a study area an average-sized lake on the Sarata River in the Republic of Moldova. This study is based on regular observations on the Sărata Nouă Lake during the last 6 years (2016 to 2021), covering all phenological periods: migration, breeding, and wintering. The field observations were carried with a monthly frequency during the migration and breeding season, while the wintering observations were carried out every two or three months.

During breeding seasons we carried out point counts and line transects, which were equally distributed in all types of habitats to meet $100 \%$ coverage. To estimate the migration and wintering population, we used point observations in order to cover the entire surface of the lake. During the field studies we used binoculars (Zeiss, 8X45), field scope (Swarovski, 20x - 60x) and specific bird identification books (Collins bird guide, 2nd edition, 2009; Ghid pentru identificarea păsărilor, 2017).

\section{Results and discussions}

During the 2016-2021, we documented the occurrence of 126 bird species, out of which 109 were migratory, 75 breeding and 37 wintering. These 126 species represent around 46\% of the total number of bird species registered in the Republic of Moldova. Taxonomically, the 126 bird species recorded during our study are distributed in 16 orders of the Aves class, the Passeriformes order being the most well represented (37 species) (tab. 1).

Table 1. List of birds observed in the study area structured on phenological seasons (xR - regular breeder, $\mathrm{xS}$ - sporadic breeder)

\begin{tabular}{|c|c|c|c|c|}
\hline \multirow[t]{2}{*}{ No } & \multirow[t]{2}{*}{ Species } & \multicolumn{3}{|c|}{ Phenological season } \\
\hline & & Migration & Breeding & Wintering \\
\hline & ord. Anseriformes & & & \\
\hline 1 & Cygnus olor & $\mathbf{x}$ & $\mathbf{x S}$ & $\mathbf{x}$ \\
\hline 2 & Tadorna ferruginea & $\mathbf{x}$ & $\mathbf{x S}$ & \\
\hline 3 & Anas platyrhynchos & $\mathbf{x}$ & $\mathbf{x R}$ & $\mathbf{x}$ \\
\hline 4 & Anas crecca & $\mathbf{x}$ & & $\mathbf{x}$ \\
\hline 5 & Anas acuta & $\mathbf{x}$ & & \\
\hline 6 & Spatula querquedula & $\mathbf{x}$ & & \\
\hline 7 & Spatula clypeata & $\mathbf{x}$ & & \\
\hline 8 & Mareca penelope & $\mathbf{x}$ & & $\mathbf{x}$ \\
\hline 9 & Mareca strepera & $\mathbf{x}$ & & \\
\hline 10 & Aythya ferina & $\mathbf{x}$ & & \\
\hline \multirow[t]{2}{*}{11} & Aythya fuligula & $\mathbf{x}$ & & $\mathbf{x}$ \\
\hline & ord. Galliformes & & & \\
\hline \multirow[t]{2}{*}{12} & Phasianus colchicus & & $\mathbf{x R}$ & $\mathbf{x}$ \\
\hline & ord. Podicipediiformes & & & \\
\hline 13 & Podiceps cristatus & $\mathbf{x}$ & & $\mathbf{x}$ \\
\hline
\end{tabular}




\begin{tabular}{|c|c|c|c|c|}
\hline & ord. Columbiformes & & & \\
\hline 14 & Columba palumbus & $\mathbf{x}$ & $\mathbf{x R}$ & \\
\hline 15 & Streptopelia turtur & $\mathbf{x}$ & $\mathbf{x R}$ & \\
\hline \multirow[t]{2}{*}{16} & Streptopelia decaocto & $\mathbf{x}$ & $\mathbf{x R}$ & \\
\hline & ord. Cuculiformes & & & \\
\hline \multirow[t]{2}{*}{17} & Cuculus canorus & $\mathbf{x}$ & $\mathbf{x R}$ & \\
\hline & ord. Apodiformes & & & \\
\hline \multirow[t]{2}{*}{18} & Apus apus & $\mathbf{x}$ & $\mathrm{xS}$ & \\
\hline & ord. Gruiformes & & & \\
\hline 19 & Fulica atra & $\mathbf{x}$ & $\mathbf{x R}$ & $\mathbf{x}$ \\
\hline 20 & Gallinula chloropus & $\mathbf{x}$ & $\mathbf{x R}$ & \\
\hline 21 & Rallus aquaticus & $\mathbf{x}$ & $\mathbf{x R}$ & \\
\hline 22 & Crex crex & $\mathbf{x}$ & $\mathbf{x R}$ & \\
\hline \multirow[t]{2}{*}{23} & Grus grus & $\mathbf{x}$ & & \\
\hline & ord. Chradriiformes & & & \\
\hline 24 & Himantopus himantopus & $\mathbf{x}$ & $\mathrm{xS}$ & \\
\hline 25 & Vanellus vanellus & $\mathbf{x}$ & $\mathbf{x R}$ & $\mathbf{x}$ \\
\hline 26 & Calidris pugnax & $\mathbf{x}$ & & \\
\hline 27 & Calidris alpina & $\mathbf{x}$ & & \\
\hline 28 & Calidris ferruginea & $\mathbf{x}$ & & \\
\hline 29 & Calidris minuta & $\mathbf{x}$ & & \\
\hline 30 & Actitis hypoleucos & $\mathbf{x}$ & & \\
\hline 31 & Tringa nebularia & $\mathbf{x}$ & & \\
\hline 32 & Tringa glareola & $\mathbf{x}$ & & \\
\hline 33 & Tringa totanus & $\mathbf{x}$ & & \\
\hline 34 & Tringa stagnatilis & $\mathbf{x}$ & & \\
\hline 35 & Tringa ochropus & $\mathbf{x}$ & & \\
\hline 36 & Tringa erythropus & $\mathbf{x}$ & & \\
\hline 37 & Charadrius alexandrinus & $\mathbf{x}$ & & \\
\hline 38 & Charadrius hiaticula & $\mathbf{x}$ & & \\
\hline 39 & Charadrius dubius & $\mathbf{x}$ & $\mathrm{xS}$ & \\
\hline 40 & Gallinago gallinago & $\mathbf{x}$ & & \\
\hline 41 & Limosa limosa & $\mathbf{x}$ & & \\
\hline 42 & Phalarobus lobatus & $\mathbf{x}$ & & \\
\hline 43 & Chroicocephalus ridibundus & $\mathbf{x}$ & & $\mathbf{x}$ \\
\hline 44 & Ichthyaetus melanocephalus & $\mathbf{x}$ & & \\
\hline 45 & Larus cachinnans & $\mathbf{x}$ & & $\mathbf{x}$ \\
\hline \multirow[t]{2}{*}{46} & Chlidonias hybrida & $\mathbf{x}$ & & \\
\hline & ord. Ciconiiformes & & & \\
\hline
\end{tabular}




\begin{tabular}{|c|c|c|c|c|}
\hline 47 & Ciconia nigra & $\mathbf{x}$ & & \\
\hline \multirow[t]{2}{*}{48} & Ciconia ciconia & $\mathbf{x}$ & $\mathbf{x}$ & \\
\hline & ord. Suliformes & & & \\
\hline \multirow[t]{2}{*}{49} & Phalacrocorax carbo & $\mathbf{x}$ & & $\mathbf{x}$ \\
\hline & ord. Pelecaniformes & & & \\
\hline 50 & Pelecanus onocrotalus & $\mathbf{x}$ & & \\
\hline 51 & Ardea alba & $\mathbf{x}$ & & $\mathbf{x}$ \\
\hline 52 & Ardea cinerea & $\mathbf{x}$ & $\mathbf{x R}$ & $\mathbf{x}$ \\
\hline 53 & Ardea purpurea & $\mathbf{x}$ & $\mathbf{x R}$ & \\
\hline 54 & Ardeola ralloides & $\mathbf{x}$ & $\mathrm{xS}$ & \\
\hline 55 & Ixobrychus minutus & $\mathbf{x}$ & $\mathbf{x R}$ & \\
\hline 56 & Nycticorax nycticorax & $\mathbf{x}$ & $\mathbf{x R}$ & \\
\hline 57 & Egretta garzetta & $\mathbf{x}$ & $\mathbf{x S}$ & \\
\hline 58 & Botaurus stellaris & $\mathbf{x}$ & $\mathbf{x R}$ & \\
\hline 59 & Platalea leucorodia & $\mathbf{x}$ & $\mathbf{x S}$ & \\
\hline \multirow[t]{2}{*}{60} & Plegadis falcinellus & $\mathbf{x}$ & & \\
\hline & ord. Accipitriformes & & & \\
\hline 61 & Accipiter gentilis & & $\mathbf{x R}$ & \\
\hline 62 & Accipiter nisus & $\mathbf{x}$ & $\mathbf{x R}$ & \\
\hline 63 & Milvus migrans & $\mathbf{x}$ & $\mathbf{x S}$ & \\
\hline 64 & Circus cyaneus & $\mathbf{x}$ & & $\mathbf{x}$ \\
\hline 65 & Circus aeruginosus & $\mathbf{x}$ & $\mathbf{x R}$ & \\
\hline 66 & Buteo buteo & $\mathbf{x}$ & $\mathrm{xR}$ & $\mathbf{x}$ \\
\hline 67 & Buteo rufinus & & $\mathbf{x R}$ & \\
\hline 68 & Haliaeetus albicilla & $\mathbf{x}$ & & \\
\hline 69 & Circaetus gallicus & $\mathbf{x}$ & & \\
\hline 70 & Falco tinnunculus & $\mathbf{x}$ & $\mathbf{x R}$ & \\
\hline 71 & Falco subbuteo & $\mathbf{x}$ & $\mathbf{x R}$ & \\
\hline 72 & Pandion haliaetus & $\mathbf{x}$ & & \\
\hline \multirow[t]{2}{*}{73} & Clanga pomarina & $\mathbf{x}$ & $\mathbf{x R}$ & \\
\hline & ord. Bucerotiformes & & & \\
\hline \multirow[t]{2}{*}{74} & Upupa epops & $\mathbf{x}$ & $\mathbf{x R}$ & \\
\hline & ord. Coraciiformes & & & \\
\hline 75 & Alcedo atthis & $\mathbf{x}$ & $\mathbf{x R}$ & \\
\hline \multirow[t]{2}{*}{76} & Merops apiaster & $\mathbf{x}$ & $\mathbf{x R}$ & \\
\hline & ord. Piciiformes & & & \\
\hline 77 & Dendrocopos syriacus & & $\mathbf{x R}$ & $\mathbf{x}$ \\
\hline 78 & Dendrocopos major & & $\mathbf{x R}$ & $\mathbf{x}$ \\
\hline 79 & Dryobates minor & & $\mathbf{x R}$ & $\mathbf{x}$ \\
\hline
\end{tabular}




\begin{tabular}{|c|c|c|c|c|}
\hline & ord. Passeriformes & & & \\
\hline 90 & Oriolus oriolus & $\mathbf{x}$ & $\mathbf{x R}$ & \\
\hline 91 & Lanius collurio & $\mathbf{x}$ & $\mathbf{x R}$ & \\
\hline 92 & Lanius excubitor & & $\mathrm{xS}$ & $\mathbf{x}$ \\
\hline 93 & Lanius minor & $\mathbf{x}$ & $\mathbf{x R}$ & \\
\hline 94 & Corvus frugilegus & $\mathbf{x}$ & $\mathbf{x R}$ & $\mathbf{x}$ \\
\hline 95 & Coloeus monedula & $\mathbf{x}$ & $\mathbf{x R}$ & $\mathbf{x}$ \\
\hline 96 & Corvus cornix & $\mathbf{x}$ & $\mathbf{x R}$ & $\mathbf{x}$ \\
\hline 97 & Garrulus glandarius & $\mathbf{x}$ & $\mathbf{x R}$ & $\mathbf{x}$ \\
\hline 98 & Cyanistes caeruleus & $\mathbf{x}$ & $\mathbf{x R}$ & $\mathbf{x}$ \\
\hline 99 & Parus major & $\mathbf{x}$ & $\mathbf{x R}$ & $\mathbf{x}$ \\
\hline 100 & Panurus biarmicus & $\mathbf{x}$ & $\mathbf{x R}$ & $\mathbf{x}$ \\
\hline 101 & Galerida cristata & $\mathbf{x}$ & $\mathbf{x R}$ & $\mathbf{x}$ \\
\hline 102 & Acrocephalus arundinaceus & $\mathbf{x}$ & $\mathbf{x R}$ & \\
\hline 103 & Acrocephalus scirpaceus & $\mathbf{x}$ & $\mathbf{x R}$ & \\
\hline 104 & Locustella luscinioides & $\mathbf{x}$ & $\mathbf{x R}$ & \\
\hline 105 & Hirundo rustica & $\mathbf{x}$ & $\mathbf{x R}$ & \\
\hline 106 & Delichon urbicum & $\mathbf{x}$ & $\mathbf{x R}$ & \\
\hline 107 & Riparia riparia & $\mathbf{x}$ & $\mathbf{x R}$ & \\
\hline 108 & Sturnus vulgaris & $\mathbf{x}$ & $\mathbf{x R}$ & $\mathbf{x}$ \\
\hline 109 & Turdus philomelos & $\mathbf{x}$ & $\mathbf{x R}$ & \\
\hline 110 & Turdus merula & $\mathbf{x}$ & $\mathbf{x R}$ & \\
\hline 111 & Lullula arborea & $\mathbf{x}$ & $\mathbf{x R}$ & \\
\hline 112 & Alauda arvensis & $\mathbf{x}$ & $\mathbf{x R}$ & \\
\hline 113 & Luscinia luscinia & $\mathbf{x}$ & $\mathbf{x R}$ & \\
\hline 114 & Phylloscopus collybita & $\mathbf{x}$ & $\mathbf{x R}$ & \\
\hline 115 & Troglodytes troglodytes & $\mathbf{x}$ & & $\mathbf{x}$ \\
\hline 116 & Motacilla alba & $\mathbf{x}$ & $\mathbf{x R}$ & \\
\hline 117 & Motacilla flava & $\mathbf{x}$ & $\mathbf{x R}$ & \\
\hline 118 & Saxicola rubicola & $\mathbf{x}$ & $\mathbf{x R}$ & \\
\hline 119 & Oenanthe oenanthe & $\mathbf{x}$ & $\mathbf{x R}$ & \\
\hline 120 & Coccothraustes coccothraustes & $\mathbf{x}$ & $\mathbf{x R}$ & $\mathbf{x}$ \\
\hline 121 & Fringilla coelebs & $\mathbf{x}$ & $\mathbf{x R}$ & $\mathbf{x}$ \\
\hline 122 & Fringilla montifringilla & $\mathbf{x}$ & & $\mathbf{x}$ \\
\hline 123 & Carduelis carduelis & $\mathbf{x}$ & $\mathbf{x R}$ & $\mathbf{x}$ \\
\hline 124 & Emberiza calandra & $\mathbf{x}$ & $\mathbf{x R}$ & $\mathbf{x}$ \\
\hline 125 & Passer montanus & $\mathbf{x}$ & $\mathbf{x R}$ & $\mathbf{x}$ \\
\hline 126 & Passer domesticus & $\mathbf{x}$ & $\mathbf{x R}$ & $\mathbf{x}$ \\
\hline
\end{tabular}




\section{Migration}

Being on the East-Elbic migration route, the lake is a very important stop for an impressive number of migratory birds, which use the location as a feeding and resting site during the spring and autumn migration. In spring, the Sărata Nouă lake hosts regular migrants such as Vanellus vanellus, Calidris pugnax, Spatula querquedula, Spatula clypeata, Mareca penelope, Anas acuta, Aythya ferina, sometimes in big numbers. For example, on 31st of March, 2017, we encountered 250 individuals of Garganey (Spatula querquedula), the majority being males resting on the lake. On the same day we counted around 850 individuals of Black-headed gulls (Chroicocephalus ridibundus).

The autumn migration unfolds starting with middle August, in some years even late July, bringing the first individuals of various wader species that begin their journey towards south: Wood sandpiper (Tringa glareola), Common redshank (T. totanus), Common greenshank ( $T$. nebularia), Common sandpiper (Actitis hypoleucos), Black-winged stilt (Himantopus himantopus), Ruff (Calidris pugnax) (tab. 1). Late July and August is also a suitable time for observing the Black stork (Ciconia nigra) migration: we recorded the presence of one individual in August 2017 and July 2020.

The peak of autumn migration is usually September, when various duck, wader and raptor species can be seen in small flocks: Eurasian teal (Anas crecca), Eurasian wigeon (Mareca penelope), Black-tailed godwit (Limosa limosa), Common snipe (Gallinago gallinago), Curlew sandpiper (Calidris ferruginea), Dunlin (C. alpina), Spotted redshank (Tringa erythropus) and Marsh sandpiper (T. stagnatilis) (Table no 1). In 2016, in late September, we encountered a big flock of grey wagtails (Motacilla alba), numbering 326 individuals, that were feeding on the ground near the lake shore. This period also brings less common and frequent species, such as Little Stint (Calidris minuta) and Common Ringed Plover (Charadrius dubius), that were noticed on September 29th, 2019. Also in September of 2019 we observed a single bird of Kentish Plover (Charadrius alexandrinus) and three individuals of Common Ringed Plover (Charadrius hiaticula), that were feeding on the shore in a muddy area. The white-tailed eagle (Haliaeetus albicilla) was repeatedly observed during autumn migration: 23th Sep 2017 and 10 th Aug 2019.

Some of the late migrants, that arrive in October and late November, are represented by a small number of individuals. The most notable observation from this period is a flock of 32 Ruddy shelducks (Tadorna ferruginea) and 180 Mallards (Anas platyrhynchos) spotted on the 27th of November, 2019.

Every year, during the migration seasons, we've also encountered species that are considered rare in the Republic of Moldova and very rare for this particular location. In this regard, on 3rd September 2016 we noticed a Red-necked phalarope (Phalaropus lobatus) individual, feeding alone. This was the second observation of the species in the Republic of Moldova and the first for this region [1]. In March 2018 we observed a flock of 10 cranes (Grus grus) flying across the lake. In April 2017 we recorded an Osprey individual (Pandion haliaetus) hunting for fish above the lake. Another rare raptor species observed at the Sarata-Noua lake was the 
Short-toed snake eagle (Circaetus gallicus) which was seen on the 23th of September, 2017.

We also encountered species that were never registered before in the Republic of Moldova, such as the Mediterranean Gull (Ichthyaetus melanocephalus). The bird was observed twice in late March (2017), feeding among 240 Black-headed Gulls on the lake.

\section{Breeding season}

Due to the multitude of habitats during the nesting period, we have registered various types of bird species: aquatic, woodland, farmland species, as well as birds adapted to open spaces, meadows and pastures. In summer, regular breeders are: Mallard (Anas platyrhynchos), Common coot (Fulica atra), Moorhen (Gallinula chloropus) (tab. 1). The marshes provide a suitable habitat for Great reed warbler (Acrocephalus arundinaceus), Eurasian Reed Warbler (A. scirpaceus) and Savi's warbler (Locustella luscinioides). In the forest strips along the lake hosts are breeding pairs of Wood pigeon (Columba palumbus), Turtle Dove (Streptopelia turtur), Eurasian golden oriole (Oriolus oriolus), Red-backed shrike (Lanius collurio) and Lesser grey shrike (L. minor) (tab. 1). The near-by poplar stripe hosts an important breeding colony consisting of 200 nests of Rook (Corvus frugilegus) and Hooded crow (C. cornix), in which the Eurasian hobby (Falco subbuteo) is known to occupy empty nests. We documented the breeding of this species in 2017 and 2019. In the neighbouring villages of Cazangic and Seliște there are several White stork (Ciconia ciconia) nests.

Among the birds which show a sporadic breeding character are the following species: Ruddy Shelduck (Tadorna ferruginea), Black-winged stilt (Himantopus himantopus), Little ringed plover (Charadrius dubius) and Mute swan (Cygnus olor) (tab. 1). A breeding pair of Ruddy Shelduck was documented in 2016, into a near-by meadow between Sărata Nouă and Romanovca [6]. The breeding evolution of this species needs to be further monitored since its current area is expanding in the south region of the Republic of Moldova. In the recent years (2020 and 2021) we documented the nesting of the Black Kite (Milvus migrans) on the strip of tree lines situated on the farmlands from the vicinity of the lake. However, several Black kite adults were spotted many times hunting on the lake or nearby.

The Great White pelican (Pelecanus onocrotalus) is a regular visitor in this area, but currently no population of this species is breeding on the lake or in its vicinity. We encountered various-sized flocks in the summer months of different years, but the highest number of great white pelicans was observed in the summer of 2016, when 120 birds were spotted for a few days feeding on the lake.

During the breeding season, the Sărata Nouă lake is also visited by various wader species which delay or still continue their spring migration: Ruff (Calidris pugnax), Common sandpiper (Actitis hypoleucos), Common greenshank (Tringa nebularia), Spotted redshank ( $T$. erythropus), Wood sandpiper (T. glareola) (tab. 1). The birds observed at the beginning of the breeding season have probably not yet reached their sexual maturity, while the birds seen later in the breeding season could be the ones that start descending immediately after mating.

It is important to mention that due to the severe drought and lack of precipitation during the summer of 2020, the Sărata Nouă lake reduced its area by $50 \%$. Although we don’t know fully 
how this impacted the local ornitofauna, we observed that the water depth decreased significantly, which made it difficult for pelicans, cormorants and other diving species to obtain their food. Also, we encountered changes in the lake shores, where wader and duck species used to gather for food and shelter. Some of these areas were rapidly colonized by reedbeds, which made feeding difficult for many waders.

\section{Wintering}

The wintering season is characterized by the presence of few bird species that use the Sărata Nouă lake as a roosting site. In mild winters, when the lake`s water is not entirely frozen, big flocks of waterbirds can be seen, such as mallards (Anas platyrhynchos) - on the 1st of January 2020 there were observed up to 2400 individuals gathered in the middle of the lake. The local diversity of bird species is rather poor during the cold season, with average-sized flocks of Mute swan (Cygnus olor), Green-winged teal (Anas crecca), Northern lapwings (Vanellus vanellus), Yellow-legged gulls (Larus cachinnans), Ardea cinerea, Ardea alba, Chroicocephalus ridibundus, Podiceps cristatus. Due to the short distance to the Prut river, small flocks of Great cormorant (Phalacrocorax carbo) reach the lake to feed constantly. The highest number of great cormorants was registered on 28 february 2020 when 68 individuals were observed.

The presence of Hen Harrier (Circus cyaneus) and Common Buzzard (Buteo buteo) is common during the winter months, with few individuals spotted almost every year in the near-by area, probably preying on small passerines or rodents.

\section{Bibliography}

1. Ajder V., Cioflec V., Bolboacă L. E., Grosu I., Baltag E. Ș. New bird species recorded in Republic of Moldova during 2011-2014. International Zoological Congress of "Grigore Antipa" Museum 19 - 22 November 2014 Bucharest, Romania.

2. Cazac V., Mihailescu C. Resursele acvatice ale Republicii Moldova. Apele de suprafata. Chișinău, Ed. Știința, 2010, Vol.1, 248 p.

3. Gîlcă G. şi a., Afluenţii rîului Prut, Rîul Sărata. INQUA - Moldova, 2001.

4. Ion C., Doroșencu A., Baltag E., Bolboaca L. Migrația Paserifomelor in Estul României. Editura Al. I Cuza, Iași, 2009.

5. Miron A. Flora şi vegetaţia pajiştilor din lunca rîului Sărata. Mediul Ambiant . 2006, nr. 5(29), p. 31-35.

6. Ursul S., Ajder V., Petrencu L., Baltag E. Ş. Ruddy shelduck distribution in the Republic of Moldova. IX-th International Conference of Zoologists: Sustainable use, protection of animal world and forest management in the context of climate change, Book of Abstracts, Chișinău, 2016, p. 85-86.

7. Wetlands International 2002. Waterfowl Population Estimates, 3rd edn. Wetlands International Global Series No. 12, Wageningen, The Netherlands.

8. Ресурсы поверхностных вод СССР, Описания рек и озер и расчеты основных характеристик их режима, Том 6, Украина и Молдавия, Вып. 1, Западная Украина и Молдавия (без бассейна р. Днестра), Гидрометеоиздат, Ленинград, 1978

9. http://www.apelemoldovei.gov.md/pageview.php?1=ro\&idc=134\&id=1172 